https://doi.org/10.18485/iipe_euchanges.2021.ch22

\title{
THE RESULTS OF ECONOMIC CO-OPERATION BETWEEN THE EU AND CHINA AMID THE COVID-19 PANDEMIC
}

\author{
Katarina ZAKIĆ ${ }^{1}$ \\ Meixing SUN ${ }^{2}$
}

\begin{abstract}
The global Covid-19 pandemic has profoundly altered the course of economic history and development, and it is significant to observe and analyse the various facets of those changes. The main aim of this paper is to analyse the results of economic co-operation between the European Union (EU) and China amid the coronavirus outbreak. To that end, the paper examines trade and investments patterns before and during the Covid-19 pandemic. Data from Eurostat, Chinese Ministry of Commerce (MOFCOM) and Rhodium Group, from 2010 to 2020, are used for descriptive statistical analysis. After suffering many setbacks in Q1 and Q2, the volume of volume of trade between the EU and China increased in Q3 2020, but its structure changed, with medical supplies becoming its primary component. Foreign direct investment (FDI) flows are low relative to the sizes of both markets. On the other hand, the EU-China Comprehensive Agreement on Investment, expected to be signed in 2021, will in all likelihood increase FDIs.

Keywords: European Union, China, economic co-operation, results, Covid19 pandemic.
\end{abstract}

\footnotetext{
${ }^{1}$ Research Fellow at the Institute of International Politics and Economics. E-mail: katarina@diplomacy.bg.ac.rs

The paper presents the findings of a study developed as part of the research project entitled 'Serbia and challenges in international relations in 2021', financed by the Ministry of Education, Science, and Technological Development of the Republic of Serbia, and conducted by the Institute of International Politics and Economics, Belgrade.
}

${ }^{2}$ MA, Nankai University. E-mail: sunmeixing2017@gmail.com 


\section{THE PANDEMIC AND THE GLOBAL ECONOMY}

Many events have over the past century affected global economic development: two world wars, the Great Depression, numerous regional conflicts, and epidemics, as well as the 2009 global financial downturn. These disasters have had a profound effect on economic history and development. Yet, the current Covid-19 pandemic is unprecedented in its impact. The unknown virus has taken more than two million lives and changed the world beyond recognition.

The many macroeconomic and microeconomic setbacks and issues made an economic recession unavoidable. It was and remains difficult for governments to address the complicated situations that transcend current knowledge of how economies function in crises. The only thing now known for certain is that resolving the problems with the world's economy will take time, and that the pace of recovery will depend on how quickly the pandemic is stopped.

The health and economic situation has changed frequently and dramatically, prompting governments to implement a variety of measures. The International Monetary Fund (IMF), World Bank, and the Organisation for Economic Co-operation and Development (OECD) have repeatedly adjusted their estimates of the pandemic's impact on the global economy. The economic forecasts were grim in April and September 2020, at the time of spikes in coronavirus cases. The final global economic results for 2020 were not available at the time of writing, ${ }^{3}$ but preliminary figures exist that highlight the impact of the crisis. According to Jackson et al. (2020) for the US Congress, the IMF estimated global growth would stand at $-4.4 \%$ in 2020, with the OECD predicting $-4.5 \%$, and the World Bank $-5.2 \%$ (Jackson, 2020, p. 23). 'The World Trade Organization (WTO) estimated that global trade volumes could fall by $9.2 \%$ in $2020^{\prime}$ (ibid, p. 27). Analysis by the United Nations Conference on Trade and Development (UNCTAD) revealed foreign direct investments (FDIs) fell by $49 \%$ in the first six months of 2020 relative to 2019 (ibid, p. 31). Moreover, the IMF has stated that, between 2020 and 2025, the loss of global economic output will amount to $\$ 28$ trillion, and that 120 million jobs will be lost permanently in the tourism sector (ibid, $p$. 3). The same study warns that between 100 and 110 million people globally could enter extreme poverty (ibid, p. 1). Whilst noting all countries face

${ }^{3}$ January 2021. 
difficulties, the IMF paper emphasises that developing countries and regions will be hit the hardest.

The relationship between the EU and China emerged as a key global bilateral economic relationship during the 2020 pandemic. The EU and China are among the top three economies globally, and the impact of their relations extends to other economies as well. ${ }^{4}$ In an economic sense, the trade and investments dealings between these two entities after the 2020 coronavirus outbreak merit closer attention, because these point to not just bilateral trends but global economic movements as well.

\section{ECONOMIC CO-OPERATION BETWEEN THE EU AND CHINA: FROM 'HONEYMOON' TO 'STRATEGIC COMPETITOR'}

For reasons of space, this study will review only a limited sample of the extensive literature on the pre-pandemic co-operation between the EU and China. The review will look at the work of both Eastern and Western researchers.

The importance accorded by the EU to China is revealed in a study done for the European Parliament, which presents a detailed analysis of bilateral trade and investment (European Union Policy Department, DirectorateGeneral for External Policies, 2020, p. 1-76). Trade relations are analysed from various angles, such as trade imbalances, changes in global supply chains, competition in third markets, and trade in services. In addition, the study discusses anti-dumping issues, trade disputes between China and the US, as well as the impact of the Belt and Road Initiative (BRI) on China's trade with the EU. Investments are examined from two perspectives, where a general overview is followed by a discussion of the EU-China bilateral investment treaty. The study is comprehensive, and each chapter includes a set of conclusions.

Xin Chen has published extensive work on China-EU economic relations, both on trade and investments $(2009,2013,2017)$. His work looks at the historical development of trade and investments, as well as analysing current and future relations. Chen (2009) distinguishes between several

\footnotetext{
${ }^{4}$ Such as members of the Association of South East Asian Nations (ASEAN) and Western Balkan countries. Trade and global supply chains are evolving, with countries making new trade and manufacturing partners, and such trends seem set to follow trends in EU-China co-operation.
} 
historical phases in the trade and economic relations between the EU and China: 1) 'waking up and warming up' in the 1970s and 1980s; 2. 'downs and ups' in the 1990s; 3) the 'honeymoon', from 2000 to 2005; and 4) the 'post-honeymoon' phase of 'certainty and uncertainty'. His later analysis (2017) presents figures clearly showing the interdependence of the Chinese and EU economy, and, whilst the two have their fair share of disputes and problems, according to Chen the only solution is to communicate better and understand each other's point of view. His proposition for both sides is to be more pragmatic and concentrate efforts not only on political dialogue but on macroeconomic and enterprise-level dialogue as well (2017, p. 90).

Eckhardt (2019) presents a historical timeline of trade disputes from a legal perspective. He emphasizes the importance of China's accession to the World Trade Organization (WTO) and the subsequent changes in the country's trading relations. According to Eckhardt, these relationships have gone through three phases: 1) 1978 to 1989, dominated by European protectionist measures against a China unable to prevent them; 2) 1990 to 2002, in which China greatly improved trade relations, but EU protectionist measures remained in place; and 3) the current phase, after China's accession to the WTO, 'characterized by increased politicization between the EU and China but also among EU member states' (2020, p. 1).

Chinese investments in the EU have been equally interesting for researchers. Knoerich and Miedtank, who investigated the patterns of Chinese investment in Europe, observe that those differ from traditional investment models that usually come from the West and Japan. These authors identify a number of idiosyncrasies of Chinese investments in Europe, including such important factors as their late entry, speed, policy of seeking strategic assets, and primary involvement of state-owned companies (2018, pp. 7-8).

Dreger and Schüler also examine investment patterns of China in Europe, concluding that Chinese outward FDI (OFDI) in Europe were connected with market size and extent of bilateral trade between China and each European country. Greenfield investments were usually the preferred 'method of investment in regions with less sound institutions and markets with less competitive pressure' (Dreger \& Schüler, 2017, p. 160).

Discussing the influence of BRI on economic co-operation between China and the EU, Wang (2015) writes that this initiative was the second opportunity for the two entities to improve their strategic partnership and engage in mutually beneficial collaboration. An assessment of BRI investments in Europe by Zakić and Radišić showed that BRI has had a 
positive impact on Chinese investments in Europe, highlighting that EU countries have benefited the most (2017, pp. 32, 34).

Even though economic relations were improving, in March 2019 President of the European Commission Ursula von der Leyen reiterated the narrative adopted by her predecessor Jean-Claude Juncker by formally declaring China 'a strategic competitor for the EU whilst failing to reciprocate market access and maintain a level playing field; an economic competitor in the pursuit of technological leadership, and a systemic rival promoting alternative models of governance' (European Commission, 2019c, p.1; Barkin, 2020). This constituted official confirmation of the EU's view of China as both an important partner and a rival. It took only 20 years to digress from the 'honeymoon' to the stage of 'strategic competitors' and 'systemic rivals'.

\section{THE EU AND CHINA ECONOMIC RELATIONS AMID COVID-19 PANDEMIC: NARRATIVE AND ANALYSIS}

After the coronavirus pandemic was declared in March 2020, the economic and in particular the political relationship between the EU and China became unsteady and characterized by difficult challenges for both sides. On a positive note, both parties sent medical help to each other when it was needed the most. By contrast, economic relations suffered, especially in the first two quarters of 2020, whilst political tensions grew. In Q2, global trade fell to its lowest level in modern economic history (Brodzicki, 2020), and this was reflected in EU-China trade relations as well. The first three months of 2020 were especially difficult for China, whilst Europe faced its worst crisis in Q2. As expected, the many uncertainties faced by businesses led to a decline in investment. In June 2020, UNCTAD forecast that FDI would fall in 2020 by $40 \%$ relative to 2019 (UNCTAD, 2020, p. 2). The total value of EU-China investments has also fallen, but the final figure still remains unknown.

Henry Tillman, CEO of consulting company Grisons Peak, was among the first to provide economic data and analysis about EU-China co-operation during the first month of the pandemic. In May 2020, Tillman noted positive trends for European investments in China had been in evidence before the pandemic started. These investments started to increase in 2018, with the largest investors coming from France, the Netherlands, Spain, Belgium, and Switzerland (Global Times). In the first month of the pandemic, EU investments in China's health sector increased, and other signs were in evidence indicating that the upward trend in EU investments in China was set 
to continue in the second part of 2020. By contrast, the volume of China's trade with the EU declined in the first four month of 2020, whilst that with ASEAN countries increased, in a trend that continued in the latter part of the year.

In May 2020, Nicholas Chapuis, the EU Ambassador to China, wrote in Asia Europe Journal that in the first month of the pandemic the 'pre-existing plans for deepening EU-China co-operation' had been 'temporarily sidetracked as both the EU and China are fully mobilized to tackle what has now become a truly global problem' (p. 201). 'We count on China to work with us in framing a globally coordinated economic recovery strategy', added Chapuis (p. 202). He also noted that, once the pandemic is over, the main task for the EU and China will be to help the global economy recover, especially in the fields of trade, investments and green recovery.

During the 22nd bilateral EU-China, held remotely on 22 June 2020, Ms von der Leyen emphasized that market access barriers and investment regulations must be jointly worked upon and negotiated with China (Whalen Benson, 2020). At the same summit, Chinese President Xi Jinping stated that China and the EU were the "two major forces for world peace and stability" and "two major markets for world development and prosperity' (ibid).

Le Corre and Brattberg (July 2020) noted that, before the pandemic, China and the EU had hoped to 'put their differences aside. But now the relationship is in free fall, with deep uncertainty about what comes next.'

In a recent report by the European Think-Tank Network on China (ETCN), Seaman referred to the Covid-19 pandemic as both bringing China and the EU closer together and taking them further apart, whilst also revealing the existing fractures between EU members in their approaches to China (2020, p. 7).

In summary, although China has declared its commitment to continued strengthening and improvement of bilateral relations, the same cannot be said of the EU (Stanojević, 2020). Political speeches made by EU officials and researchers reveal divided opinions about co-operation during the pandemic and different conclusions about what should be done in the future.

\section{METHODOLOGY}

A descriptive statistical analysis is used for analysis of trade and investment from 2010 to 2019, as well as during the pandemic in 2020. It should be emphasized that the paper was written in late 2020 and early 2021, so only data for the first three quarters of 2020 will be presented, as most 
institutions that collect and issue statistics will not have released figures for Q4 2020 by the time this paper has been published.

Economic results reported by international institutions vary depending on the methodology used to calculate final data, and those differences can significantly distort analysis (Hanemann \& Huotari, 2017), which is why it is important to carefully choose data sets. The time span is ten years, and the focus is on trade and investment. Eurostat trade and FDI data are used for the EU, and figures from MOFCOM are utilized for China. Because both Eurostat and MOFCOM publish data with a delay of 6 to 12 months, the paper uses 2019 and 2020 investment figures produced by Rhodium Group and published by Eurostat.

\section{FINDINGS AND DISCUSSION}

\section{A) Trade}

As noted above, EU-China trade had been growing constantly, and until the pandemic the two had seen decades of successful co-operation. China is the EU's second-largest partner, whilst the EU is China's number one trading partner. China ran a significant trade surplus over the EU in the previous decade, as shown in Figure 1.

FIGURE 1. EU-CHINA TRADE, 2009-2019 (EUR MN)

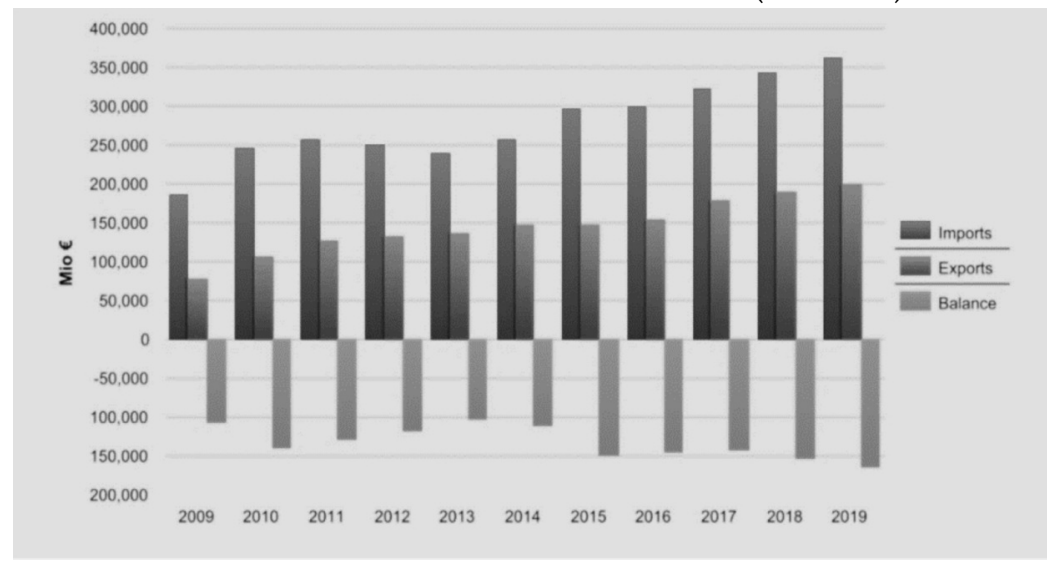

Source: Eurostat, (2020a, September 05). European Union,

Trade with China, p. 2, available online at

webgate.ec.europa.eu/isdb_results/factsheets/country/details_china_en.pdf. 
According to a Eurostat study (2020e, March) on EU-China trade statistics in 2019, "In 2019, EU exports of manufactured goods (87\%) had a higher share than primary goods $(12 \%)$. The most exported manufactured goods were machinery \& vehicles $(55 \%)$, followed by other manufactured products (18\%) and chemicals (14\%). In 2019, EU imports of manufactured goods $(97 \%)$ also had a higher share than primary goods $(2 \%)$. The most imported manufactured goods were machinery \& vehicles (54\%), followed by other manufactured products (37\%) and chemicals (5\%).' The same study lists the following countries as the biggest importers from China in 2019: the Netherlands (with imports valued at EUR 88 billion), Germany (EUR 76 billion), and Italy (EUR 31 billion). The biggest exporters to China were Germany (with exports worth EUR 96 billion), France (EUR 20 billion), and the Netherlands (EUR 13 billion).

Due to the pandemic, trade between China and the EU fell in the first two quarters of 2020 only to recover subsequently. In the first ten months of 2020, China was the EU's main trade partner, given that the volume of EUChina trade increased in the first three quarters by $3.4 \%$ year-on-year, whereas trade between the EU and the US fell $13 \%$ year-on-year in the same period (Eurostat, 2020b, p. 2). Chinese trade with ASEAN countries also showed a huge increase (Global Times, 2020), as expected due to lockdowns in most European countries and the resulting disruption of value chains. That did not mean, however, that intra-EU trade increased: on the contrary, it fell by $10.8 \%$ year-on-year (Eurostat, 2020 b, p. 1).

According to Eurostat (2020c, June): 'The EU's seasonally adjusted trade (imports + exports) with China fell from $€ 46.5$ billion in January 2020 to $€ 43.1$ billion in February 2020. In March 2020, EU's trade with China fell further to $€ 41.9$ billion, while in April 2020 it bounced back above its January 2020 level to $€ 49.0$ billion. This increase was mainly led by a sharp increase in imports from China ( $+€ 3.5$ billion and $+€ 6.8$ billion compared with January and March 2020 respectively), and was largely due to an increase in imports of specific made-up textile articles such as textile face masks, surgical masks, disposable face masks, and single use drapes.' On the exports side, the greatest change was the significant drop in exports of cars and motor vehicles $(-71 \%)$ and aircraft and aircraft equipment $(-89 \%)$ from the EU' (ibid). Whilst data are not available for the whole of 2020, trade is obviously recovering, but the structure of traded goods has changed. It will be interesting to see whether the changes will persist in 2021 and 2022 or whether trade will revert to former patterns. 


\section{B) Investment}

Foreign direct investment flows between China and the EU are substantial, but not as large as may be expected given some of the world's largest investors are EU member states, and that China has for decades been a top destination for foreign investment.

Investments were a source of major disputes between the EU and China even before the pandemic. Eight rounds of negotiations took place in the run-up to 2020 between the two on the Comprehensive Agreement on Investments (CAI). News that emerged in late 2020 suggest the two parties are very close to reaching a final agreement. In the long run, the CAI will provide a platform for closer co-operation.

Figure 2 and Table 1 show Eurostat data about the EU's outward FDI in China. A new report commissioned by the European Parliament (2020), 'EUChina trade and investment relations in challenging times', presents ChinaEU FDI flows between 2008 and 2017, calculated according to a newly adopted methodology that presents FDI statistics on an asset/liability basis instead of using the directional principle.

FiguRe 2. ANNUAL CHINA-EU DIRECT INVESTMENT FLOWS, 2008-2017 (EUR MN)

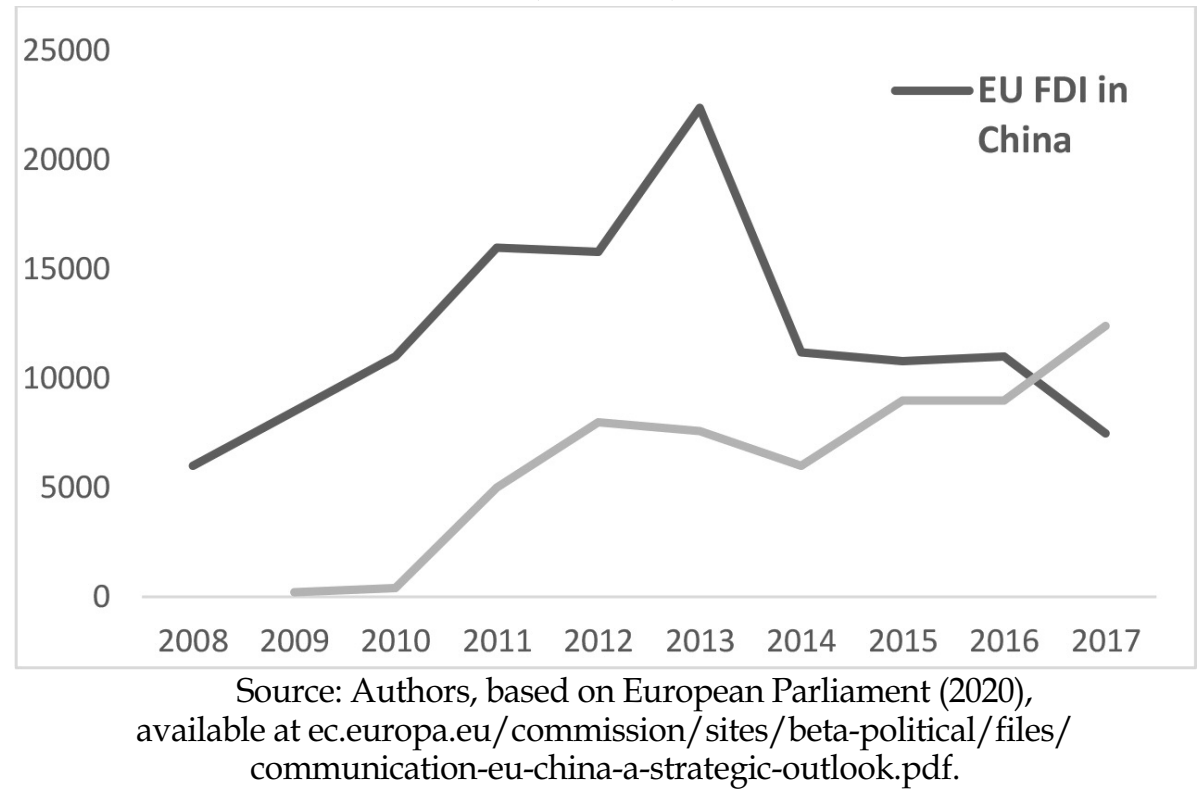


After seeing a general decline during the 2008 global economic downturn, EU FDIs in China doubled after the crisis ended, from EUR 5 bn in 2008 to EUR 17 bn in 2011, reaching a high of EUR 22 bn in 2013 (Figure 2). As early as 2014, inflows of FDIs from the EU returned to 2010 levels of some EUR 11 bn, where they remained until 2016. There was another sharp decline to EUR 7.5 bn in 2017, according to the latest available data presented in Figure 2.

Chinese investment in the EU also began to rise sharply after the global downturn. As early as 2012, FDIs exceeded EUR 7.5 bn. No sudden fluctuations were registered thereafter, with the figures trend following a moderate and stable upward trend. In 2015, inflows of Chinese FDIs into the EU amounted to around EUR 9 bn, the same as in 2016, when they reached and then exceeded the EU's FDIs to China. Chinese investments in the EU, however, continued to grow until 2017, when they amounted to a maximum of EUR 12 bn (Figure 2).

The stock of EU-China FDIs is unexpectedly low given to the sizes of the two economies. Nevertheless, from 2008 to 2017, 'the stock of EU FDI in China grew from EUR 54 billion to EUR 178 billion - an increase of 225\%' (GarciaHerrero et al., 2020, p. 8). Table 1 presents data on the outward stock of the EU's FDIs in China from 2013 to 2018. Here, too, there are significant differences relative to the 2020 report due to methodological changes. Data for 2017 according to the new methodology reveal a value of EUR 178 bn, whilst the figure under the directional presentation is EUR 171.6 bn (Table 1).

TABLE 1. STOCK OF EU OUTWARD FDIS IN CHINA, 2013-2018, EUR MN

\begin{tabular}{|c|c|}
\hline Year & FDIs (EUR mn) \\
\hline 2013 & 120,189 \\
\hline 2014 & 136,227 \\
\hline 2015 & 161,991 \\
\hline 2016 & 170,335 \\
\hline 2017 & 171,654 \\
\hline 2018 & 175,326 \\
\hline
\end{tabular}

Source: Eurostat database, Balance of payments - international transactions

(bop_6), BOP_FDI6_GEO, available online at

ec.europa.eu/eurostat/web/balance-of-payments/data/database. 
Data on Chinese outward FDI in the EU as published by MOFCOM are presented in Table 2. As noted above, due to differences in methodology, Eurostat and MOFCOM data are not comparable, but both datasets are taken into account in the interests of transparency and to present both points of view.

TABLE 2. STOCK OF ChINESE OUTWARd FDIs IN THE EU, 2010-2019, USD BN

\begin{tabular}{|c|c|}
\hline Year & FDIs (USD bn) \\
\hline 2010 & 124.97 \\
\hline 2011 & 202.91 \\
\hline 2012 & 315.38 \\
\hline 2013 & 401.00 \\
\hline 2014 & 542.10 \\
\hline 2015 & 644.00 \\
\hline 2016 & 698.37 \\
\hline 2017 & 860.15 \\
\hline 2018 & 907.39 \\
\hline 2019 & 939.12 \\
\hline
\end{tabular}

Source: MOFCOM, , Statistical Bulletins of China's Outward Foreign Direct Investment 2010-2019

After the introduction of the 'Going Global' strategy in China's 10th Five Year Plan, and after the country allowed private companies to invest abroad in 2003, the level of Chinese investment worldwide rose significantly year after year to reach a record high in 2016 (Zakić \& Radišić, 2017, pp. 37-38). The 'Going Global' approach allowed China to engage in major mergers and acquisitions (M\&A) in the EU, which raised concern amongst European countries about China's strategic interests in the European economy, especially in the IT sector. However, Chinese investments in the EU have been declining constantly due to the European bloc's adoption in 2019 of the Foreign Direct Investment Screening Regulation and greater Chinese orientation towards opportunities in BRI countries.

According to Kratz et al. (2020), Chinese M\&A in Europe were worth EUR 11.7 billion in 2019, as opposed to 17.4 bn in 2018 and EUR 29.2 bn in 2017. 
These authors also noticed several emerging trends regarding Chinese investments in Europe in 2019: China was investing more in Northern EU Member State; Chinese state investment declined by $11 \%$; and the main sectors for investments were consumer products and services, as well as ICT (ibid).

On the other hand, EU investors had been investing in China for years, but to a lesser extent than Chinese ones did in the EU. Even though European investors were interested in Chinese business opportunities, legal, tax and know-how restrictions hindered them from investing more. That being said, it also ought to be noted that, in 2017, EU's investments in China (USD $7.17 \mathrm{bn}$ ) were worth three times as much as those from the US (GarciaHerrero et al., 2020, p. 27), and were mainly directed into the manufacturing sector. Moreover, much EU investment came to the mainland via Hong Kong due to security and tax reasons (ibid, pp. 27-28).

Global investments declined in 2020 due to pandemic, with many companies seeking greater liquidity by laying off workers and forgoing expansion. Similar effects can be seen in both the EU and China.

Eurostat has published quarterly reports produced by Rhodium Group about EU-China investments. Data are available for the first three quarters of 2020 and are presented in Tables 3 and 4. The figures reveal that the EU has invested more in China than the opposite, with these investments valued at some USD $2.7 \mathrm{bn}$. Germany, the Netherlands, and France remained the largest sources of EU investment over all three quarters, and the automotive industry was the principal sector for the investments.

TABLE 3. EU FDIS IN CHINA, JANUARY-SEPTEMBER 2020

\begin{tabular}{|c|c|c|c|}
\hline EU FDIs in China & Q1 & Q2 & Q3 \\
\hline $\begin{array}{l}\text { Value } \\
\text { of completed } \\
\text { acquisitions } \\
\text { and greenfield } \\
\text { investments }\end{array}$ & USD 1.6 bn & USD 2.3 bn & USD 1.6 bn \\
\hline Industries & $\begin{array}{l}\text { 1. Automotive } \\
\text { 2. Consumer } \\
\text { products } \\
\text { and services } \\
\text { 3. Agriculture } \\
\text { and food }\end{array}$ & $\begin{array}{l}\text { 1. Automotive } \\
\text { 2. Basic materials } \\
\text { 3. Agriculture } \\
\text { and food }\end{array}$ & $\begin{array}{l}\text { 1. Automotive } \\
\text { 2. Consumer } \\
\text { products } \\
\text { and services } \\
\text { 3. Health } \\
\text { and biotech }\end{array}$ \\
\hline
\end{tabular}




\begin{tabular}{|l|l|l|l|}
\hline EU FDIs in China & \multicolumn{1}{|c|}{ Q1 } & \multicolumn{1}{c|}{ Q2 } & \multicolumn{1}{c|}{ Q3 } \\
\hline $\begin{array}{l}\text { Main sources } \\
\text { of EU investment }\end{array}$ & $\begin{array}{l}\text { 1. Germany } \\
\text { 2. The Netherlands } \\
\text { 3. France }\end{array}$ & $\begin{array}{l}\text { 1. Germany } \\
\text { 2. The Netherlands } \\
\text { 3. France }\end{array}$ & $\begin{array}{l}\text { 1. Germany } \\
\text { 2. The Netherlands } \\
\text { 3. France }\end{array}$ \\
\hline
\end{tabular}

Source: Rhodium Group, Cross Border Monitor (CBM) Q1 to Q3 2020, available online at https://trade.ec.europa.eu/doclib/cfm/doclib_section.cfm?sec=120

The value of Chinese FDIs in the EU from January to September 2020 was USD $2.8 \mathrm{bn}$. There were no obvious patterns regarding industries that China invested in, but real estate and hospitality do stand out. Most Chinese outwards investments were directed into Germany, France, and Romania.

TABLE 4. Chinese FDIs IN THE EU, JANUARY- SePTEMBER 2020

\begin{tabular}{|l|l|l|l|}
\hline $\begin{array}{l}\text { Chinese FDIs } \\
\text { in the EU }\end{array}$ & \multicolumn{1}{|c|}{ Q1 } & \multicolumn{1}{|c|}{ Q2 } & \multicolumn{1}{c|}{ Q3 } \\
\hline $\begin{array}{l}\text { Value of } \\
\text { completed } \\
\text { acquisitions } \\
\text { and greenfield } \\
\text { investments }\end{array}$ & USD 1.3 bn & USD 502 mn & USD 1 bn \\
\hline Industries & $\begin{array}{l}\text { 1. Real estate } \\
\text { and hospitality } \\
\text { 2. Consumer } \\
\text { products } \\
\text { and services } \\
\text { 3. Basic materials }\end{array}$ & $\begin{array}{l}\text { 1. Transport, } \\
\text { utilities and } \\
\text { infrastructure } \\
\text { 2. Entertainment } \\
\text { 3. Automotive }\end{array}$ & $\begin{array}{l}\text { 1. Energy } \\
\text { 2. Real estate } \\
\text { and hospitality } \\
\text { 3. Electronics }\end{array}$ \\
\hline $\begin{array}{l}\text { Main targets } \\
\text { of EU investment }\end{array}$ & $\begin{array}{l}\text { 1. Germany } \\
\text { 2. Romania } \\
\text { 3. France }\end{array}$ & $\begin{array}{l}\text { 1. Spain } \\
\text { 2. Germany } \\
\text { 3. The Czech } \\
\text { Republic }\end{array}$ & $\begin{array}{l}\text { 1. France } \\
\text { 2. Portugal } \\
\text { 3. Romania }\end{array}$ \\
\hline
\end{tabular}

Source: Rhodium Group, Cross Border Monitor (CBM) Q1 to Q3 2020, available online at https:// trade.ec.europa.eu/doclib/cfm/doclib_section.cfm?sec=120 
It is also worth noting a new trend regarding global inward FDIs in China. Hanemann and Rosen stated that flows into China have been increasing since January. 'In the first five months of 2020, foreign M\&A into China totalled $\$ 9$ billion, surpassing Chinese outbound M\&A activity in both volume and value terms for the first time in a decade' (Hanemann \& Rosen, 2020). Judging by Rhodium Group's reports, 2020 and 2021 will be successful for FDIs into China.

Factors that go beyond the scope of in this paper but that will impact economic relations between the EU and China include the US PresidentElect Joseph J. Biden Jr.'s policy towards China; the speed with which a Covid-19 vaccine will become universally available; and the impact of 'Dual Circulation', China's new development policy, on the EU-China relationship, and at the end, the future development of the BRI.

\section{CONCLUSION}

Nearly one year on from the start of the pandemic, it is obvious that everything has changed, from people's daily lives and social interactions, to travelling, politics, and economics. The pandemic is not over and the full impact effects of the changes that will occur remains unknown.

Economic measures taken by governments to prevent the devastating effects of Covid-19 on their economies will provide some relief and help companies and the general public survive these challenging times. Although those actions will mitigate some of the impacts, the pandemic has revealed all structural issues in national economies that had previously remained hidden, either intentionally or unintentionally. The economic motto in this pandemic can be said to be 'adapt or disappear' and the fight against Covid19 is a challenging one for economies.

The pandemic has affected the volume of trade and supply chains between the EU and China. Trade volume decreased in the first two quarters in 2020 but recovered after that. Due to pandemic times and needs, type of the products that were traded changed. Co-operation in the investment field, on the contrary, was less successful and was fraught with many problems. According to available data until January 2021, Europe outward FDI to China were higher than China's outward FDI to Europe. Late in the year, both parties issued statements claiming they had in principle reached an agreement about the EU-China CAI after nine rounds of negotiations (European Commission, 2020b). 
It is worth mentioning that changes in trade and investments between these partners affect many other countries they co-operate with. For some, changes to economic links between the EU and China will be a great opportunity, whilst for others they will pose a threat. This was a key reason for producing this paper, which will hopefully give some insights into data for 2020.

However, the authors believe that EU-China economic relations are so deeply intertwined that any dramatic changes would not be in the best interest of either party. In times of the pandemic, when economies are faring worse than previously, radical changes cannot benefit anyone.

Nevertheless, some changes will occur, and these will probably affect investments the most. Even though China wants to have a greater investment presence in the EU, obstacles introduced even before the pandemic (e.g. the EU's investment screening mechanism) will reduce Chinese investments in the EU. On the other hand, investors from the EU began to increase their investments before the pandemic started, and that trend continued even in 2020.

China's 2020 economic results indicate it is one of the world's few nations where the outcomes are positive and better than expected. In these circumstances, when everything is uncertain, the investors are attempting to downsize risk by investing in countries achieving good results and where they expect good returns on their investment. This is currently the case with China, and this is the reason why European investments are increasing, sometimes entering the mainland directly, and sometimes via Hong Kong.

To conclude, the EU and China are partners whose co-operation had already been close before the coronavirus outbreak, whilst the 2020 pandemic has affected the extent of trade and type of traded goods, as well as causing significant changes in investments as well.

\section{REFERENCES}

Brodzicki, T. (2020, September 07). Top 10 economies: Q2 2020 the worst quarter on record in trade with first signs of a sustained but very gradual upturn, IHS Markit, retrieved from https://ihsmarkit.com/researchanalysis/top-10-economies-q2-2020-the-worst-quarter-on-record-intrade.html. Accessed 20 August 2020. 
Barkin, N. (2020, January 13). Europe's moment of truth with China, Politico, retrieved from https://www.politico.eu/article/europes-moment-oftruth-with-china-trade-eu/, Accessed 10 September 2020.

Chapuis, N. (2020). EU-China relations in the time of COVID-19. Asia Europe Journal 18, pp. 201-203. https:// doi.org/10.1007/s10308-020-00572-5

Chen, X. (2009). Policy Evolution of the China-EU Trade and Economic Relationship. Working paper series on European Studies, Institute of European studies, Chinese academy of social sciences, 3(4), pp. 1-23.

Chen, X. (2013). New trends in EU's economic relations with China, Global Economic Observer, Institute for World Economy, Romanian Academy, p. 11-18, retrieved from http://nos.iem.ro/123456789/613. Accessed 09 September 2020.

Chen, X. (2017). China-EU Economic and Trade Relations (2003-2013), in: Research Series on the Chinese Dream and China's Development Path, Hong Zhou Editor, Social Sciences Academic Press (China) and Springer (Singapore), pp. 41-55. doi: 10.1007/978-981-10-1145-0

Dreger, C. \& Schüller, M. (2017). Chinese foreign direct investment in Europe follows conventional models, DIW Economic Bulletin, Deutsches Institut für Wirtschaftsforschung (DIW), Berlin, 7 (14/15), pp. 155-160.

Eckhardt, J. (2019). Law and Diplomacy in EU-China Trade Relations: A Historical Overview. Law and Diplomacy in the Management of EU-Asia Trade and Investment Relations, Routledge, London, pp. 58-74. doi: 10.4324/9780429461729-4

European Commission (2020a, February 13). EU-China Comprehensive Agreement on Investment, retrieved from https://trade.ec.europa.eu/ doclib/press/index.cfm?id=2115, Accessed 20 August 2020.

European Commission (2020b, December 30). EU and China reach agreement in principle on investment, retrieved from https://ec. europa.eu/commission/presscorner/detail/en/IP_20_2541, Accessed 02 January 2021.

European Commission and HR/VP contribution to the European Council (2019c, March 12). EU-China - A strategic outlook, European Commission, Strasbourg, pp. 1-16, retrieved from https://ec.europa.eu/ commission/sites/beta-political / files/communication-eu-china-astrategic-outlook.pdf, Accessed 20 September 2020

European Parliament (2020), EU-China trade and investment relations in challenging times, Policy Department, Directorate-General for External Policies, Belgium, pp. 1-76. doi: 10.2861/393445 
Eurostat (2020a, May 08). European Union Trade with China, retrieved from https://webgate.ec.europa.eu/isdb_results/factsheets/country/details _china_en.pdf, Accessed 20 August 2020.

Eurostat (2020b, December 16). Euro area international trade in goods surplus $€ 30.0$ bn, Eurostat News Release - Euro Indicators, No. 183/2020, retrieved from https://trade.ec.europa.eu/doclib/docs /2013/december/tradoc_151969.pdf, Accessed 02 December 2020.

Eurostat (2020c, June 22). Impact of the COVID-19 on EU trade with China, retrieved from https:/ / ec.europa.eu/ eurostat/web/ products-eurostatnews/-/EDN-20200622-1 Accessed 20 September 2020.

Eurostat (2017d, July 20). European Union direct investments (BPM6) (bop_fdi6) - Reference Metadata in Euro SDMX Metadata Structure (ESMS), retrieved from https://ec.europa.eu/eurostat/cache/ metadata/en/bop_fdi6_esms.htm, Accessed 20 September 2020.

Eurostat (2020e March). China-EU - international trade in goods statistics, retrieved from https://ec.europa.eu/eurostat/statistics-explained/ index.php?title=China-EU_-_international_trade_in_goods_statistics\# EU_and_China_in_world_trade_in_goods, Accessed 20 September 2020

Eurostat database, Balance of payments - international transactions (bop and bop_6), retrieved from https://ec.europa.eu/eurostat/web/ balance-of-payments/data/database, Accessed 20 September 2020.

Garcia-Herrero, A., Wolff, G. \& Felbermayr, G. (2020). Introduction, in: EUChina trade and investment relations in challenging times, European Union Policy Department, Directorate-General for External Policies, Belgium. doi: 10.2861/393445 (pdf), pp. 1-11.

Garcia-Herrero, A., Xu, J. \& Sandkamp, A. (2020). China-European Union Investment, in: EU-China trade and investment relations in challenging times, European union Policy Department, Directorate-General for External Policies, Belgium pp. 27-32. doi: 10.2861/393445

Global Times (2020, May 19). China-EU economic cooperation increasing amid COVID-19, Global Times, retrieved from https:// www.globaltimes. cn/content/1188851.shtml, Accessed 20 September 2020.

Hanemann, T. \& Rosen, D. H. (2020, June 18). “Who's Buying Whom? COVID-19 and China Cross-Border M\&A Trends", Rhodium Group, retrieved from https://rhg.com/research/whos-buying-whom, Accessed 20 September 2020.

Hanemann. T. \& Huotari, M. (2017 December). Chinese Direct Investment in Europe: What Available Data Sources Tell Us, in: Chinese Investment 
in Europe A Country-Level Approach, Edited by: John Seaman, Mikko Huotari, Miguel Otero-Iglesias, French Institute of International Relations (Ifri), Elcano Royal Institute, Mercator Institute for China Studies.

Jackson, J. K., Weiss, M. A., Schwarzenberg, A. B., Nelson, R. M., Sutter, K. M. \& Sutherland, M. D. (2020, December 23). Global Economic Effects of COVID-19, Congressional Research Service, US Government, https://fas.org/sgp/crs/row/R46270.pdf, accessed 2 January 2021.

Knoerich, J. \& Miedtank, T. (2018 December). The Idiosyncratic Nature of Chinese Foreign Direct Investment in Europe, CESifo Forum, Volume 19, pp. 3-8.

Kratz, A., Huotari, M., Hanemann, T. \& Arcesati, R. (2020 April). Chinese FDI in Europe: 2019 update/ Special Topic: Research Collaborations, Rhodium Group (RHG) and the Mercator Institute for China Studies (MERICS), Berlin, Germany, pp. 1-23.

Le Corre, P. \& Brattberg, E. (2020, July 09). How the Coronavirus Pandemic Shattered Europe's Illusions of China, Carnegie Endowment for International Peace, retrieved from https://carnegieendowment.org/ 2020/07/09/how-coronavirus-pandemic-shattered-europe-s-illusionsof-china-pub-82265, Accessed 20 September 2020.

MOFCOM (2010-2019). Statistical Bulletin of China's Outward Foreign Direct Investment, Ministry of Commerce, PR China.

Rhodium Group (2020, April 23). Cross Border Monitor (CBM): Peoples Republic of China - European Union Direct Investment: 1Q 2020 Update: Public Version, https://trade.ec.europa.eu/doclib/docs/ 2020/june/tradoc_158775.pdf, accessed 2 January 2021.

Rhodium Group (2020, July 30). Cross Border Monitor (CBM): Peoples Republic of China - European Union Direct Investment: 2Q 2020 Update: Public Version, https://trade.ec.europa.eu/doclib/docs/ 2020/september/tradoc_158922.pdf, accessed 2 January 2021.

Rhodium Group (2020, November 04). Cross Border Monitor (CBM): People's Republic of China - European Union Direct Investment: 3Q 2020 Update: Public Version, retrieved from https://trade.ec. europa.eu/doclib/docs/2020/november/tradoc_159095.pdf, Accessed 02 January 2021.

Seaman, J. (2020, April 29). China as partner, competitor and rival amid COVID-19, in: COVID-19 and Europe-China Relations: A country level analysis, edited by John Seaman, European Think-tank Network on 
China French Institute of International Relations, pp. 5-11 retrieved from https://www.ifri.org/sites/default/files/atoms/files/etnc_special_rep ort_covid-19_china_europe_2020.pdf, Accessed 2 September 2021.

Stanojević N. (2020). Effects of China's New Silk Road on the participating economies, Eliva press.

UNCTAD (2020, June 16). World Investment Report 2020, UN Publications, New York, USA, pp. 1-245, retrieved from https:/ / unctad.org/ system/ files/official-document/wir2020_en.pdf, Accessed 02 January 2021.

Wahlen Benson C. (2020, June 30). EU-China Summit Addresses Trade, Climate Change, COVID-19 Pandemic, SDG Knowledge Hub, retrieved from https://sdg.iisd.org/news/eu-china-summit-addresses-tradeclimate-change-covid-19-pandemic/, Accessed 02 October 2021.

Wang, Y. (2015). China's "New Silk Road": A Case Study in EU-China Relations, in Xi's Policy Gambles: The Bumpy Road Ahead, Editors Alessia Amighini and Axel Berkofsky, Istituto per gli Studi di Politica Internazionale, Milano, Italy, pp. 93-109, retrieved from http://www.ispionline.it/it/EBook/CHINA.POLICY.2015/CHINA.P OLICY_Cap.6_EBOOK.pdf, Accessed 02 October 2021.

Zakić, K. \& Radišić B. (2017). The Results and Challenges of Chinese "Go Global" Policy, The Review of International Affairs, LXVIII (1168), pp. 36-55.

Zakić, K. \& Radišić B. (2019). Influence of the Belt and Road Initiative on Chinese Investments in Europe Case study: Balkan Countries; Editors in Charge: Liu Zuokui and Lađevac Ivona The Cooperation between China and Balkan Countries under the "Belt and Road" Initiative, Chinese Academy of Social Science, Beijing, China, pp. 27-53. 